\title{
Delayed re-bleeding after removal of a radial arterial cannula
}

\author{
Natsumi Hatanaka (D, Kumiko Tanabe, Mayuko Yamada and Hiroki lida
}

Keywords: Arterial cannulation, Complication, Delayed re-bleeding, Hematoma

\section{To the editor}

Hematoma after arterial cannulation is not so very rare but tends to occur during cannulation and immediately after decannulation. We report a case of delayed re-bleeding after the removal of a radial arterial cannula.

\section{Case presentation}

A 74-year-old woman underwent revision total arthroplasty under general anesthesia with epidural anesthesia. She had no comorbidities and regularly took loxoprofen sodium hydrate. Examinations before the operation had no abnormal findings. Her right radial artery was punctured and cannulated uneventfully with a 22-gauge BD Insyte ${ }^{\mathrm{Tx}}$ IV Catheter (Japan Becton, Dickinson and Company). The amount of bleeding was $320 \mathrm{~mL}$, and she received $160 \mathrm{~mL}$ of autologous freshfrozen plasma. The arterial cannula was immediately removed at the end of anesthesia. An anesthesiologist achieved hemostasis at the punctured site with $5 \mathrm{~min}$ of compression by hand. She exited the operation room with a hemostasis device (STEPTY; Nichiban Co., Ltd., Tokyo, Japan) over the puncture site. The device was removed $2 \mathrm{~h}$ after the operation, when her bleeding was confirmed to have stopped. She was observed every $2 \mathrm{~h}$ without re-bleeding at the puncture site, and her systolic blood pressure was kept under $120 \mathrm{mmHg}$. A nurse noted bleeding from the puncture site $13 \mathrm{~h}$ after the operation. She compressed the site by hand and called a duty doctor, who advised watchful waiting. They confirmed the stop of bleeding and noticed slightly edema and internal hemorrhaging around the puncture site. The next day, internal hemorrhaging and edema from the fingers to the middle of the upper arm were noted (Fig. 1). Her right forearm was stiff and swollen, but her hand movement was not restricted. She noted no paralysis or paresthesia. The pulse oximeter detected normal waves on her right fingers. Based on these symptoms, compartment syndrome was not suspected. The circumferences of her forearm at two points (proximal wrist joint and distal elbow) were checked eight times over 2 days, with no increase in size noted. The internal hemorrhaging and edema were gradually diminished.

\section{Discussion}

Indwelling arterial catheters is generally a safe procedure with few serious complications $[1,2]$. The radial artery is the most common site for cannulation because of a low rate of associated complications [3], although hematoma is occasionally noted. The incidence rate of transradial puncture-related hematoma is $14.4 \%$ [1], which is higher than that of hematoma related to cardiac catheterization for angiography or percutaneous coronary intervention (PCI) $(0.5 \%$ to 13\%) [4], even though the cannulas used for angiography and PCI are larger than those used in the operating room and patients frequently receive antiplatelet agents after PCI [3]. Patients who are older and have a lower body mass index or body weight and thinner skin folds are reportedly at risk of developing hematoma after transradial catheterization [4].

\footnotetext{
* Correspondence: natsumi19890626@gmail.com

Department of Anesthesiology and Pain Medicine, Gifu University Graduate School of Medicine, Gifu 501-1193, Japan
} 


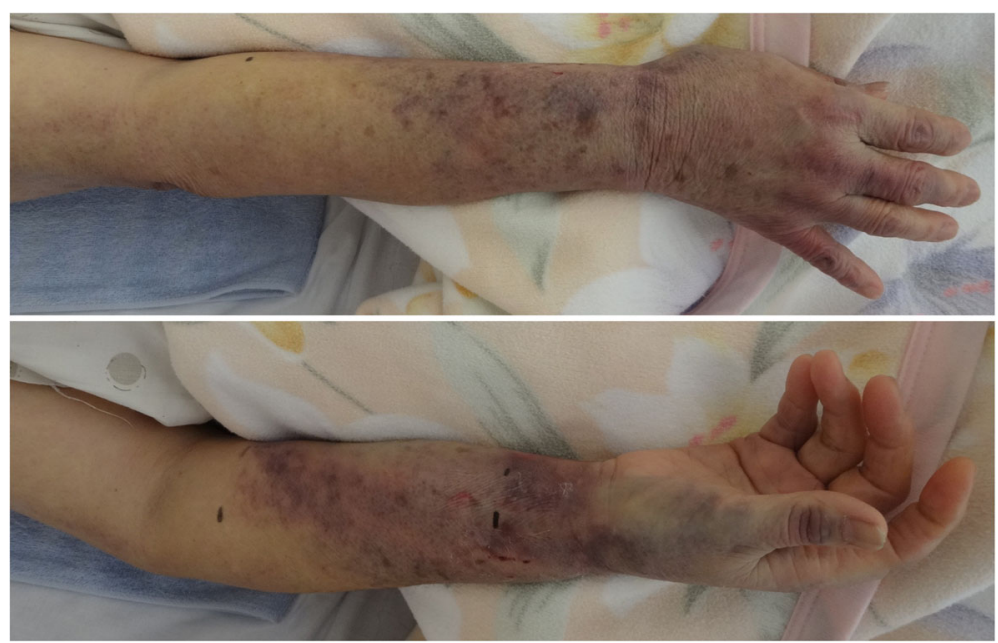

Fig. 1 A picture of the right forearm. Two days after the operation, internal hemorrhaging and edema from the fingers to the middle of the upper arm were noted. The right forearm was stiff and swollen

The radial arterial puncture site is usually manually compressed at the time of decannulation. However, basic questions such as how long and strongly compression should be performed remain unclear.

\section{Conclusion}

We should check for hemostasis frequently in cooperation with the ward staff.

\section{Abbreviation}

PCl: Percutaneous coronary intervention

\section{Availability of data and materials}

Please contact the author for data requests.

\section{Authors' contributions}

$\mathrm{NH}$ encountered this case and wrote the manuscript. MY helped write the manuscript. $\mathrm{HI}$ and $\mathrm{KT}$ gave instructions on writing manuscript. All authors have read and approved the final manuscript.

\section{Ethics approval and consent to participate} Not applicable.

\section{Consent for publication}

Written informed consent was obtained from the patient for the publication of this case report.

\section{Competing interests}

The authors declare that they have no competing interests.

\section{Publisher's Note}

Springer Nature remains neutral with regard to jurisdictional claims in published maps and institutional affiliations.

Received: 9 August 2018 Accepted: 30 August 2018

Published online: 11 September 2018

\section{References}

1. Scheer BV, Perel A, Pfeiffer UJ. Clinical review: complications and risk factors of peripheral arterial catheters used for haemodynamic monitoring in anaesthesia and intensive care medicine. Crit Care. 2002;6:199-204.

2. Slogoff S, Keats AS, Arlund C. On the safety of radial artery cannulation. Anesthesiology. 1983;59:42-7.
3. Nuttall G, Bruckhardt J, Hadley A, Kane S, Kor D, Marienau MS, Schroeder DR, Handlogten K, Wilson G, Oliver WC. Surgical and patient risk factors for severe arterial line complications in adults. Anesthesiology. 2016;124:590-7.

4. Li A, Yeih D, Chen K, Chu S, Weng C. The thicker the skin fold, the less hematoma development: a novel parameter other than body mass index associated with transradial vascular complication. Angiology. 2007; 58:597-602.

\section{Submit your manuscript to a SpringerOpen ${ }^{\circ}$ journal and benefit from:}

- Convenient online submission

- Rigorous peer review

- Open access: articles freely available online

High visibility within the field

- Retaining the copyright to your article

Submit your next manuscript at $\boldsymbol{\nabla}$ springeropen.com 